University of Nebraska - Lincoln

DigitalCommons@University of Nebraska - Lincoln

\title{
Effects of Burial and Soil Condition on Postharvest Mortality of Boll Weevils (Coleoptera: Curculionidae) in Fallen Cotton Fruit
}

\author{
S. M. Greenberg \\ USDA-ARS, sgreenberg@weslaco.ars.usda.gov
}

A. T. Showler

USDA-ARS

T. W. Sappington

USDA-ARS

J. M. Bradford

USDA-ARS

Follow this and additional works at: https://digitalcommons.unl.edu/usdaarsfacpub

Part of the Agricultural Science Commons

Greenberg, S. M.; Showler, A. T.; Sappington, T. W.; and Bradford, J. M., "Effects of Burial and Soil Condition on Postharvest Mortality of Boll Weevils (Coleoptera: Curculionidae) in Fallen Cotton Fruit" (2004). Publications from USDA-ARS / UNL Faculty. 728.

https://digitalcommons.unl.edu/usdaarsfacpub/728

This Article is brought to you for free and open access by the U.S. Department of Agriculture: Agricultural Research Service, Lincoln, Nebraska at DigitalCommons@University of Nebraska - Lincoln. It has been accepted for inclusion in Publications from USDA-ARS / UNL Faculty by an authorized administrator of DigitalCommons@University of Nebraska - Lincoln. 


\title{
Effects of Burial and Soil Condition on Postharvest Mortality of Boll Weevils (Coleoptera: Curculionidae) in Fallen Cotton Fruit
}

\author{
S. M. GREENBERG, ${ }^{1}$ A. T. SHOWLER, T. W. SAPPINGTON ${ }^{2}$, AND J. M. BRADFORD ${ }^{3}$
}

ARS-USDA APMRU, Kika de la Garza Subtropical Research Center, 2413 East Highway 83, Weslaco, TX 78596

J. Econ. Entomol. 97(2): 409-413 (2004)

\begin{abstract}
Effects of soil condition and burial on boll weevil, Anthonomus grandis grandis Boheman, mortality in fallen cotton, Gossypium hirsutum L., fruit were assessed in this study. During hot weather immediately after summer harvest operations in the Lower Rio Grande Valley of Texas, burial of infested fruit in conventionally tilled field plots permitted significantly greater survival of weevils than in no-tillage plots. Burial of infested squares protected developing weevils from heat and desiccation that cause high mortality on the soil surface during and after harvest in midsummer and late summer. A laboratory assay showed that burial of infested squares resulted in significantly greater weevil mortality in wet than in dry sandy or clay soils. Significantly fewer weevils rose to the soil surface after burial of infested bolls during winter compared with bolls set on the soil surface, a likely result of wetting by winter rainfall. A combination of leaving infested fruit exposed to heat before the onset of cooler winter temperatures and burial by tillage when temperatures begin to cool might be an important tactic for reducing populations of boll weevils that overwinter in cotton fields.
\end{abstract}

KEY WORDS Anthonomus grandis grandis, boll weevil, cotton, overwintering, tillage

Cultural tactics Play a Role in the integrated management of cotton, Gossypium hirsutum L., pests (Reynolds et al. 1975, Summy and King 1992). Conservation tillage has found some acceptance among growers because it reduces soil erosion and conserves soil moisture more than conventionally tilled systems (Stevens et al. 1992, Smart and Bradford 1996). Tillage operations modify soil habitats where some pest (Troxclair and Boethel 1984) and beneficial insects (McPherson et al. 1982, Funderburk et al. 1988) reside during parts of their life cycles. These modifications can alter survival or development of soil- and foliageinhabiting insects (Herzog and Funderburk 1986). Areawide cotton stalk destruction followed by a hostfree period has been a long-standing cultural method for control of the boll weevil, Anthonomus grandis grandis Boheman (Howard 1896), in the Lower Rio Grande Valley of Texas (Norman et al. 1984; Summy et al. 1985, 1986, 1993a,b), but specific factors related to postharvest boll weevil mortality, including soil type and condition, and burial depth of infested fruit, have not been evaluated. The objectives of this study were to determine survival of boll weevils in fallen infested fruit soon after cotton harvest in conventional and conservation tillage systems, and at different

\footnotetext{
${ }^{1}$ E-mail: sgreenberg@weslaco.ars.usda.gov.

${ }^{2}$ USDA-ARS, Corn Insects and Crop Genetics Research Unit, Genetic Bldg., Iowa State University, Ames, IA 50011.

${ }^{3}$ USDA-ARS IFNRRU Kika de la Garza Subtropical Agricultural Research Center, Weslaco, TX 78596.
}

burial soil depths, in dry or wet sandy or clay soils in the laboratory and under field conditions.

\section{Materials and Methods}

Field studies were conducted in conventional and conservation tillage cotton (variety DPL 451RR) plots, $\approx 1$ ha in area each, in Hidalgo County, Lower Rio Grande Valley, Texas. In 2000 and 2001, three and two plots of each treatment were used, respectively. Conventional stalk destruction, as commonly practiced in the Lower Rio Grande Valley, consisted shredding cotton stalks, making one pass with a heavy disk, and a final pass with a moldboard plow, generally operated to a depth of $20-25 \mathrm{~cm}$. With conservation tillage, living cotton stalks were destroyed with one pass of a stalk puller and no disking or plowing followed. These operations in both treatments were conducted during the fall before spring planting. The plots were planted on 2 March 2000 and 27 February 2001, respectively.

Fallen Fruit Collections before Harvest. One day before chemical defoliation on 22 July 2000 and 26 July 2001, fallen squares and bolls (fruit) were collected from randomly selected one by $10-\mathrm{m}$ sections of furrow in each treatment $(2000, n=60 ; 2001, n=40)$. The fruit were dissected in the laboratory and those that were infested with living or dead immature stages of boll weevils, or bore a circular teneral adult exit hole $\approx 1 \mathrm{~mm}$ in diameter, were counted. Differences between the two treatments were detected using the two sample $t$-test (Analytical Software 1998). 
Boll Weevil Survival in Naturally Infested Fruit after Tillage. After harvest, two and one 1-ha plots in 2000 and 2001, respectively, were tilled on 2 August 2000 and 4 August 2001. Three and one plots in 2000 and 2001, respectively, were not tilled. Seven days after tillage, the fruits were collected in both treatments from randomly selected one by $10-\mathrm{m}$ sections of furrow. In the conservation tillage treatment, the fruits were collected from the soil surface $(2000, n=30$; $2001, n=10$ ), and in the conventional tillage treatment, from the upper $25 \mathrm{~cm}$ of soil $(2000, n=10 ; 2001$, $n=5$ ). Numbers of fruit infested with living boll weevils were counted. The data were analyzed using the two sample $t$-test to detect treatment differences (Analytical Software 1998).

Boll Weevil Survival in Laboratory Infested Fruit after Tillage. Three conventional and four conservation-tilled plots, $0.4-0.8$ ha each, were used in Hidalgo County, Texas, during 2000 and 2002. Adult boll weevils were reared from infested squares collected from Lower Rio Grande Valley cotton fields during the summers of 2000 and 2002 and held in screen cages (20 by 20 by $20 \mathrm{~cm}$ ) for $5 \mathrm{~d}$ in environmental chambers at $28 \pm 1^{\circ} \mathrm{C}, 65 \% \mathrm{RH}$, and a photoperiod of 14:10 (L:D) $\mathrm{h}$. The weevils were fed fresh squares daily, and each cage contained a cotton wick saturated with water. After $5 \mathrm{~d}, 50$ females were removed and provided with 250 7-9-mm-diameter squares. After $24 \mathrm{~h}$, squares with oviposition punctures were placed in screen cages. When $\geq 75 \%$ of the developing larvae were second or third instars, determined by measuring larval head capsule widths in 10 randomly selected fruit (Parrott et al. 1970), each fruit was tied to one end of a $10-\mathrm{cm}$ string, the other end of which was tied to a 1-m-long cord. Five of the $10-\mathrm{cm}$ strings were tied at $20-\mathrm{cm}$ intervals to the cord. One day after harvest, the cords were laid across furrows for $7 \mathrm{~d}$ at randomly selected sites in the conservation tillage treatment $(2000, n=105$ cords; 2002 , $n=60$ cords). In the conventional tillage treatment, where squares and other plant parts are mostly buried (A.T.S., unpublished data), cords $(2000, n=45 ; 2002, n=$ 20) were buried $15-25 \mathrm{~cm}$ deep for $7 \mathrm{~d}$ in 1.1 by 0.5 by $0.25 \mathrm{~m}$ (length by width by depth) trenches at randomly selected sites. Boll weevil mortality was assessed by dissecting the squares to observe boll weevil larvae and pupae that died from heat or desiccation, or predation by ants (Curry et al. 1982, Sturm and Sterling 1986, Sterling et al. 1990).

Soil surface temperatures were recorded using HOBO H8 4-channel loggers (Onset Computer Corp., Pocasset, MA) at 90 randomly selected sites in the conservation tillage treatment in each of 2000 and 2002 , and at 20 randomly selected locations in the conventionally tilled treatment in 2000 and 2002 . The four TMC6-HA external sensors for each logger were placed next to four of the squares, and temperatures were recorded every hour. Temperatures at soil depths of $5,10,20$, and $30 \mathrm{~cm}$ were recorded every $2 \mathrm{~h}$ in four randomly selected sites in the conventionally tilled treatments by using Reotemp (San Diego, CA) thermometers. Soil moisture was recorded at depths of 25 and $30 \mathrm{~cm}$ by using the gravimetric water content method (Gardner 1986). Relative humidity was measured at a weather station $<1 \mathrm{~km}$ away.

The two sample $t$-test was used to detect treatment differences in boll weevil mortality and temperature (Analytical Software 1998). Percentage data were arcsine square root-transformed for analysis (Sokal and Rohlf 1994).

Effects of Soil Type, Moisture, and Burial Depth on Boll Weevil Mortality in the Laboratory. Assays were conducted in 15-cm-diameter, 20-cm-deep pots, each covered with a screen lid and held in an environmental. The two soil types used in this study were fine sand loam ( $84.8 \%$ sand) and clay loam ( $99.4 \%$ clay), and each type was used dry or wet, where water was added to saturation.

Ten adult boll weevils, 7-10 d old, 15-18 mg each, were placed in each pot, in one of the 16 soil treatments, sand or clay, dry or wet, $0,5,10$, or $15 \mathrm{~cm}$ in depth $(n=10)$. During the first day, the pots were observed continuously for $8 \mathrm{~h}$ to record the number of weevils that rose to the soil surface, and thereafter once on each of nine consecutive days. After $10 \mathrm{~d}$, boll weevils still buried were unearthed to determine whether they were dead.

In a similar assay, fifteen 6-9-mm-diameter squares infested with third instar boll weevils were buried in pots under $10 \mathrm{~cm}$ of each soil treatment and a control where the infested squares were kept in ventilated 15 -cm-diameter petri dishes $(n=6)$. All treatments and controls were stored in the environmental chambers. When boll weevils began to emerge in the control, the pots were checked daily for weevils. After $30 \mathrm{~d}$, the buried squares and the soil were examined for surviving weevils. Both assays were constructed in a completely randomized design. Significant differences in mean numbers of weevils between the treatments in both assays were detected using one-way analysis of variance (ANOVA), and means were separated using Tukey's honestly significant difference (HSD) (Wilkinson et al. 1992). Percentage data were arcsine square root-transformed for analysis (Sokal and Rohlf 1994).

Effects of Soil Type and Burial Depth on Boll Weevil Emergence in Winter Field Conditions. Ten 1520-mm-diameter bolls, each infested with one larval boll weevil, were buried at depths of 5,10 , and $15 \mathrm{~cm}$ under the clay or sandy soils, in a cotton field in Hidalgo County on 29 November 2002. Control bolls were placed on the surface of each soil type. A conical wire mesh cage with a 1-mm-diameter open bottom and $0.75 \mathrm{~m}$ in height with an 85-ml collection cap fastened over the cone top's 2-cm-diameter opening, was placed over each group of 10 bolls $(n=5)$. The bottom edges of the mesh cones were secured with $\geq 10 \mathrm{~cm}$ of packed clay loam to prevent emerging adult weevils from escaping. The cones were left in place for $81 \mathrm{~d}$, until 19 February 2003, when the field had to be planted with cotton. Rainfall sufficient to saturate the soils to a depth of $>15 \mathrm{~cm}$ occurred on $5 \mathrm{~d}$ at the test site. Numbers of adult boll weevils in the collection caps were counted weekly. Soil temperatures were recorded at weekly intervals at 1000 hours for $12 \mathrm{wk}$ 
Table 1. Mean ( \pm SE) boll weevil infestation of fallen fruits on the soil surface in two tillage regimes the day before defoliation, Hidalgo County, Texas, 2000 and 2001

\begin{tabular}{lllll}
\hline \hline \multirow{2}{*}{ Year } & \multirow{2}{*}{$\begin{array}{c}\text { Tillage } \\
\text { regime }\end{array}$} & $n$ & \multicolumn{2}{c}{ Fallen fruit $/ \mathrm{m}^{2}$} \\
\cline { 4 - 5 } & regimes & & Total & Infested \\
\hline 2000 & Conventional & 60 & $7.3 \pm 0.2 \mathrm{a}$ & $6.5 \pm 0.2 \mathrm{a}$ \\
& Conservation & 60 & $5.2 \pm 0.1 \mathrm{~b}$ & $4.1 \pm 0.2 \mathrm{~b}$ \\
2001 & Conventional & 40 & $6.8 \pm 0.2 \mathrm{a}$ & $3.9 \pm 0.1 \mathrm{a}$ \\
& Conservation & 40 & $5.2 \pm 0.2 \mathrm{~b}$ & $3.1 \pm 0.1 \mathrm{~b}$ \\
\hline
\end{tabular}

Means in the same column and year followed by different letters are significantly different $(P \leq 0.05)$, two sample $t$-test.

by using Reotemp thermometers $(n=3)$. Repeated measures analysis was used to detect treatment and time effects, and treatment*time interaction. Cumulative numbers of boll weevils collected in the cages were analyzed as a completely randomized design using one-way ANOVA, and means were separated using Tukey's HSD (Analytical Software 1998).

\section{Results}

Fallen Fruit Collections before Harvest. There were 1.4- and 1.3-fold more fallen fruits per square meter of furrow in the conventional than in the conservation tillage plots in $2000(t=10.6$, df $=1,118$, $P<0.0001)$ and $2001(t=5.4 ; \mathrm{df}=1,78 ; P<0.0001)$ (Table 1). Among the fallen fruits, 1.6- and 1.3-fold more were infested in the conventional tillage treatment in $2000(t=13.4 ; \mathrm{df}=1,118 ; P<0.0001)$ and $2001(t=5.4$; df $=1,78 ; P<0.0001)$ than in the conservation tillage treatment (Table 1).

Boll Weevil Survival in Naturally Infested Fruit after Tillage. The mean cumulative numbers of live weevils in infested fruit were 13.3- and 14.9-fold higher in the conventional tillage regime where they had been buried than in the conservation tillage regime on the soil surface in $2000(t=21.2 ; \mathrm{df}=1,38 ; P<0.0001)$ and $2001(t=12.0 ; \mathrm{df}=1,13 ; P<0.0001)$, respectively (Fig. 1). During this experiment, the average soil surface temperatures in the conservation tillage regime were $42.7 \pm 0.8$ and $44.2 \pm 1.1^{\circ} \mathrm{C}$ at $1000-1900$ hours in 2000 and 2001, respectively, and the minimum average temperatures were $29.0 \pm 0.2$ and $28.6 \pm 0.6^{\circ} \mathrm{C}$ at 1900-1000 hours in 2000 and 2001, respectively. The highest temperatures in both years occurred between $1200-1500$ hours ranging from 52.5 to $66.0^{\circ} \mathrm{C}$. Mean daytime soil temperatures $15-20 \mathrm{~cm}$ in depth in the conventional tillage regime were $27.8 \pm 0.1^{\circ} \mathrm{C}$ in 2000

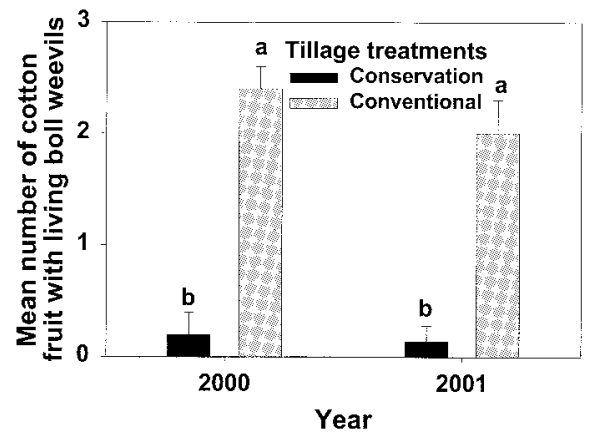

Fig. 1. Mean ( $\pm \mathrm{SE}$ ) cumulative numbers of live boll weevils in infested cotton fruit on the soil surface in conservation tillage plots or $25 \mathrm{~cm}$ below the soils surface in conventionally tilled plots, Hidalgo County, Texas, 2000 and 2001 .

and $28.7 \pm 0.1^{\circ} \mathrm{C}$ in 2001 , with the greatest temperatures (1200-1500 hours) ranging from 31 to $34^{\circ} \mathrm{C}$. Mean relative humidity was $68.8 \pm 1.6 \%$ and soil moisture at $25 \mathrm{~cm}$ in depth was $53.7 \pm 0.8 \%$.

Boll Weevil Survival in Laboratory Infested Fruit after Tillage. After $1 \mathrm{wk}$, mortalities of boll weevils in squares on the soil surface in conservation tillage plots were 4.2- and 3.4-fold greater than in squares buried in conventional tillage regime in $2000(t=13.5$; $\mathrm{df}=$ $1,148 ; P<0.0001)$ and $2001(t=17.3$; df $=1,78 ; P<$ 0.0001 ), respectively (Table 2 ). Heat and desiccation together caused $95-100 \%$ of the boll weevil mortality in the conservation tillage treatment, but mortality was significantly lower in the conventional tillage treatment (Table 2). The mean soil surface temperature in the conservation tillage treatment was 1.5$(2000, t=6.6 ; \mathrm{df}=1,108 ; P<0.0001 ; 2002, t=6.1 ; \mathrm{df}=$ $1,108 ; P<0.0001)$ higher than at the $25-\mathrm{cm}$ soil depth in the conventional tillage treatment in 2000 and 2002 , respectively (Table 2 ). In the conservation tillage treatment, relative humidity was $65-70 \%$ and the highest soil surface temperatures of $49.2-51.5^{\circ} \mathrm{C}$ occurred between 1200 and 1500 hours. At the $25-\mathrm{cm}$ soil depth in the conventional tillage treatment, soil moisture was $45-50 \%$ and the highest temperatures of 32.5$35.0^{\circ} \mathrm{C}$ also occurred between 1200 and 1500 hours.

Effects of Soil Type, Moisture, and Burial Depth on Boll Weevil Mortality in the Laboratory. More adults moved to the surface of the dry soils, where $63.3-97.2 \%$ reached the surface from 5-, 10-, and 15-cm burial depths, whereas in the wet soils, where $0-19 \%$ of the buried weevils reached the surface from the $5-\mathrm{cm}$ soil

Table 2. Mean ( \pm SE) mortality of boll weevils in infested cotton squares after 7 d, Hidalgo County, Texas, August 2000 and 2002

\begin{tabular}{|c|c|c|c|c|c|c|}
\hline Year & Tillage regime & $n^{a}$ & Dead $/ \operatorname{cord}^{b}$ & Heat/desiccation & Ants & Temperatures $\left({ }^{\circ} \mathrm{C}\right)^{c}$ \\
\hline \multirow[t]{2}{*}{2000} & Conservation & 105 & $4.2 \pm 0.1 \mathrm{a}$ & $100 \mathrm{a}$ & $0 \mathrm{a}$ & $37.9 \pm 1.6 \mathrm{a}$ \\
\hline & Conventional & 45 & $1.0 \pm 0.1 b$ & $0 \mathrm{~b}$ & $0 \mathrm{a}$ & $25.2 \pm 0.4 \mathrm{~b}$ \\
\hline \multirow[t]{2}{*}{2001} & Conservation & 60 & $4.7 \pm 0.1 \mathrm{a}$ & $95.1 \pm 1.4 \mathrm{a}$ & $4.9 \pm 0.3 \mathrm{a}$ & $39.0 \pm 1.8 \mathrm{a}$ \\
\hline & Conventional & 20 & $1.4 \pm 0.2 b$ & $0 \mathrm{~b}$ & $0 \mathrm{a}$ & $26.4 \pm 0.8 b$ \\
\hline
\end{tabular}

\footnotetext{
${ }^{a} n$, numbers of cords used (each with five squares attached).

${ }^{b}$ Means within the same year and column followed by different letters are significantly different $(P \leq 0.05)$, two sample $t$-test.

${ }^{c}$ During both years, conservation tillage plots, $n=90$; conventional tillage plots, $n=20$.
} 
Table 3. Mean numbers $( \pm \mathrm{SE})$ of boll weevils rising to the soil surface in different soil conditions

\begin{tabular}{|c|c|c|c|c|}
\hline Soil type ${ }^{a}$ & $\begin{array}{c}\text { Soil } \\
\text { condition }\end{array}$ & $\begin{array}{l}\text { Burial } \\
\text { depth } \\
(\mathrm{cm})\end{array}$ & $\begin{array}{l}\% \text { Weevils } \\
\text { on surface } \\
\text { in } 10 \mathrm{~d}^{b}\end{array}$ & $\begin{array}{l}\% \text { survival of } \\
\text { weevils buried } \\
\text { for } 10 \mathrm{~d}^{b}\end{array}$ \\
\hline \multirow[t]{6}{*}{ Sand } & \multirow[t]{3}{*}{ Dry } & 5 & $93.0 \pm 2.1 \mathrm{a}$ & $100 \mathrm{a}$ \\
\hline & & 10 & $76.7 \pm 2.7 \mathrm{ab}$ & $100 \mathrm{a}$ \\
\hline & & 15 & $63.3 \pm 3.7 \mathrm{~b}$ & $100 \mathrm{a}$ \\
\hline & \multirow[t]{3}{*}{ Wet } & 5 & $19.0 \pm 6.2 \mathrm{c}$ & $0 \mathrm{c}$ \\
\hline & & 10 & $0 \mathrm{~d}$ & $0 \mathrm{c}$ \\
\hline & & 15 & $0 \mathrm{~d}$ & $0 \mathrm{c}$ \\
\hline \multirow[t]{2}{*}{ Control } & Dry & 0 & $100 \mathrm{a}$ & $100 \mathrm{a}$ \\
\hline & Wet & 0 & $100 \mathrm{a}$ & $100 \mathrm{a}$ \\
\hline \multirow[t]{6}{*}{ Clay } & \multirow[t]{3}{*}{ Dry } & 5 & $97.2 \pm 1.5 \mathrm{a}$ & $100 \mathrm{a}$ \\
\hline & & 10 & $89.0 \pm 2.3 \mathrm{ab}$ & $100 \mathrm{a}$ \\
\hline & & 15 & $74.0 \pm 3.0 \mathrm{~b}$ & $49.2 \pm 2.3 b$ \\
\hline & \multirow[t]{3}{*}{ Wet } & 5 & $0 \mathrm{~d}$ & $0 \mathrm{c}$ \\
\hline & & 10 & $0 \mathrm{~d}$ & $0 \mathrm{c}$ \\
\hline & & 15 & $0 \mathrm{~d}$ & $0 \mathrm{c}$ \\
\hline \multirow[t]{2}{*}{ Control } & Dry & 0 & $100 \mathrm{a}$ & $98.6 \pm 1.0 \mathrm{a}$ \\
\hline & Wet & 0 & $100 \mathrm{a}$ & $98.0 \pm 1.3 \mathrm{a}$ \\
\hline
\end{tabular}

${ }^{a}$ Sand, $84.8 \%$ sand; clay, $99.4 \%$ clay; control, weevils on soil surface; 10 adult boll weevils per replicate.

${ }^{b}$ Means within a column followed by different letters are significantly different $(P \leq 0.05)$, one-way ANOVA, Tukey's HSD, $n=10$.

depth, and none reached the surface from 10 - and 15 -cm depths $(F=388.3 ; \mathrm{df}=15,144 ; P<0.0001)$ (Table 3 ). All weevils that remained buried in dry soils were still alive after $10 \mathrm{~d}$ except at the $15-\mathrm{cm}$ depth in dry clay, where only $49.2 \pm 2.3$ boll weevils were alive. All weevils still buried in wet soils at each depth were dead $(F=420.2 ; \mathrm{df}=15,144 ; P<0.0001)$ (Table 3$)$.

Emergence of boll weevils from infested squares buried $10 \mathrm{~cm}$ in depth in the wet soils was $>24 \%$ less than in the control $(F=16.6 ; \mathrm{df}=4,25 ; P<0.0001)$, but significant differences were not detected between the dry soils and the control (Table 4 ). An average of $84 \%$ fewer weevils surfaced from buried squares in the wet than in the dry soils $(F=43.7 ; \mathrm{df}=4,25 ; P<$ 0.0001 ) (Table 4). Survival of weevils remaining buried in infested squares for $30 \mathrm{~d}$ was also less in each of the wet soil treatments than in the dry treatments $(F=$ 12.2; $\mathrm{df}=3,20 ; P<0.0001$ ) (Table 4).

Effects of Soil Type and Burial Depth on Boll Weevil Emergence in Winter Field Conditions. Mean cumulative numbers of adult boll weevils that had

Table 4. Mean ( \pm SE) boll weevil emergence from infested squares buried $10 \mathrm{~cm}$ in depth in laboratory conditions

\begin{tabular}{lcccc}
\hline \hline Soil & Condition & $\begin{array}{c}\text { \% Emergence } \\
\text { from squares }\end{array}$ & $\begin{array}{c}\text { \% Found on } \\
\text { soil surface }^{b}\end{array}$ & $\begin{array}{c}\text { Living weevils } \\
\text { buried for } \\
10 \mathrm{~d}^{b}\end{array}$ \\
\hline Sand & Dry & $72.2 \pm 4.0 \mathrm{ab}$ & $49.7 \pm 10.5 \mathrm{~b}$ & $45.3 \pm 10.4 \mathrm{a}$ \\
& Wet & $35.6 \pm 6.3 \mathrm{c}$ & $7.8 \pm 5.7 \mathrm{c}$ & $0 \mathrm{~b}$ \\
Clay & Dry & $64.4 \pm 2.8 \mathrm{ab}$ & $30.7 \pm 3.1 \mathrm{~b}$ & $30.0 \pm 8.0 \mathrm{a}$ \\
& Wet & $61.1 \pm 4.0 \mathrm{~b}$ & $4.8 \pm 2.2 \mathrm{c}$ & $0 \mathrm{~b}$ \\
Control & $\mathrm{n} / \mathrm{a}$ & $80.5 \pm 2.5 \mathrm{a}$ & $100.0 \mathrm{a}$ & \\
\hline
\end{tabular}

$\mathrm{n} / \mathrm{a}$, not applicable.

${ }^{a}$ Sand, $84.8 \%$ sand; clay, $99.4 \%$ clay; control, boll weevils on soil surface.

${ }^{b}$ Fifteen infested squares per replicate, $n=6$ replicates; means in each column followed by different letters are significantly different $(P \leq 0.05)$, one-way ANOVA, Tukey's HSD.
Table 5. Mean ( \pm SE) temperatures in different soil types and depths in a cotton field, Hidalgo County, Texas, winter 2002-2003

\begin{tabular}{lcc}
\hline \hline Soil type & \\
\hline Sandy & $\begin{array}{c}\text { Boll depth } \\
(\mathrm{cm})^{b}\end{array}$ & $\begin{array}{c}\text { Temperature } \\
\left({ }^{\circ} \mathrm{C}\right)^{c}\end{array}$ \\
& 5 & $22.8 \pm 0.7 \mathrm{~b}$ \\
Clay & 10 & $21.0 \pm 0.7 \mathrm{c}$ \\
& 15 & $19.7 \pm 0.7 \mathrm{de}$ \\
Control & 5 & $23.3 \pm 0.8 \mathrm{~b}$ \\
& 10 & $19.9 \pm 0.7 \mathrm{~d}$ \\
& 15 & $19.1 \pm 0.8 \mathrm{e}$ \\
\end{tabular}

${ }^{a}$ Sandy, $84.8 \%$ sand; clay, $99.4 \%$ clay; control, bolls placed on soil surface.

${ }^{b}$ Bolls buried on 29 November 2002

${ }^{c}$ Temperature was measured weekly for $12 \mathrm{wk}$ at 1000 hours, 29 November 2002- February 2003; means followed by different letters are not significantly different $(P \leq 0.05)$, one-way ANOVA, Tukey's HSD.

emerged from buried bolls ranged from 0 to 0.4 , and no significant differences were detected between them. However, the $4.0 \pm 0.9$ weevils collected from the nonburied control plots was significantly greater $(F=16.1 ; \mathrm{df}=6,34 ; P<0.0001)$ than the numbers collected from any of the buried bolls. Repeated measures analyses detected significant treatment effects $(F=429.6 ; \mathrm{df}=6,34 ; P<0.0001)$, and mean temperatures within each soil type, including the control, decreased with increasing depth $(P \leq 0.05$; Table 5$)$. Time effects were also significantly different $(F=$ 651.9; $\mathrm{df}=11,251 ; P<0.0001)$, and there was a treatment*time interaction $(F=14.75 ; \mathrm{df}=66,251$; $P<0.0001)$.

\section{Discussion}

Before harvest, the greater abundances of fallen non-infested and infested squares were observed in the conventionally tilled treatment than in the conservation. The conventional tillage was less vulnerable to heat- and desiccation-associated mortality because shade from the cotton canopy is more prevalent in this tillage regime (Greenberg et al. 2004). Our results indicate that the main mortality factor in postharvest fallen squares in conservation tillage regimes was high soil surface temperatures and associated desiccation. Boll weevils that were then buried by tillage had less mortality because the larvae were insulated from high temperatures and desiccation by the soil layer, which decreased temperature and increased moisture compared with conditions on the soil surface. Summy et al. (1986) found that during late August in the Lower Rio Grande Valley, boll weevil mortality was $90.8 \%$ at a $52.9^{\circ} \mathrm{C}$ average maximum soil surface temperature with temperatures $>38.0^{\circ} \mathrm{C}$ for $9.6 \mathrm{~h} / \mathrm{d}$, but mortality was only $15.7 \%$ in mid-October when maximum soil surface temperatures averaged $39.1^{\circ} \mathrm{C}$ with temperatures $>38^{\circ} \mathrm{C}$ for $2.2 \mathrm{~h} / \mathrm{d}$. In our assay using the cords of weevil-infested squares, buried weevil mortality after $1 \mathrm{wk}$ was $\geq 70 \%$ lower than on the soil surface.

Mean numbers of boll weevil adults that rose to the soil surface from different depths of dry sand or clay 
were greater than those from wet soils probably because of reduced oxygen availability and heavier, more compacted soil in the wet conditions. Also, weevils that remained buried after $10 \mathrm{~d}$ were mostly dead in the wet soils, but most were alive in dry conditions. The laboratory data agrees with the results obtained in the winter field assay in which few adult boll weevils rose to the soil surface from all three depths and both soil types probably because winter rainfall during the 81-d period resulted in compaction and reduced available oxygen, and a soil surface crust $\approx 3 \mathrm{~mm}$ thick formed a barrier. Lower temperatures at all three depths in both soil types compared with the control might have reduced buried weevil activity.

Although boll weevil survival during the hot period immediately after harvest is greater when insulated with soil in the conventionally tilled treatments, an opposite effect occurs during the winter. Wet soils result in greater mortality than dry soils, and burial of infested squares causes greater mortality than bolls on the soil surface during the cooler months. Substantial boll weevil populations remain in cotton fields in the Lower Rio Grande Valley even after the host plant is chemically defoliated and then mechanically harvested and the stalks shredded (Showler 2003). Burial of infested cotton squares by postharvest tillage operations is associated with boll weevil mortality in fallow cotton fields (A. T. S., unpublished data). These results help to understand the fates of populations of developing boll weevils as influenced by postharvest tillage practices. A combination of leaving infested cotton fruit exposed to the sun before the onset of cooler winter temperatures and burial by tillage when temperatures have cooled might be an important tool for control of boll weevil populations during the cotton-free period.

\section{Acknowledgments}

We acknowledge the technical assistance of J. Caballero, P. Carreon, J. Cavazos, L. Leal, and J. Garcia. We also thank J.R.C. Robinson and K. R. Summy for constructive reviews of the manuscript.

\section{References Cited}

Analytical Software. 1998. Statistix for Windows. Analytical Software, Tallahassee, FL.

Curry, G. L., J. R. Cate, and P.J.H. Sharpe. 1982. Cotton bud drying: contributions to boll weevil mortality. Environ. Entomol. 11: 345-350.

Funderburk, J. E., D. L. Wright, and I. D. Teare. 1988. Preplant tillage effects on population dynamic of soybean insect predators. Crop Sci. 28: 973-977.

Gardner, W. A. 1986. Water content, pp. 493-562. In A. Klute [ed.], Methods of soil analysis, part 1. Soil Sciences Society of America, Madison, WI.

Greenberg, S. M., J. R. Smart, J. M. Bradford, T. W. Sappington, J. W. Norman, and R. J. Coleman. 2004. Effects of conventional vs. conservation tillage systems on population dynamics of boll weevil (Coleoptera: Curculionidae) in dryland cotton. Subtrop. Plant Sci. (in press).

Herzog, D. C., and J. E. Funderburk. 1986. Economical bases for habitat management and cultural control, pp.
217-250. In M. Kogan [ed.], Ecological theory and integrated pest management practice. Wiley, New York.

Howard, L. O. 1896. The Mexican cotton boll weevil. U.S. Dep. Agric. Bur. Entomol. Circ. 14: 8.

McPherson, R. M., J. C. Smith, and W. A. Allen. 1982. Incidence of anthropod predators in different soybean cropping systems. Environ. Entomol. 1: 685-689.

Norman, J. W., K. R. Summy, and J. R. Cate. 1984. Boll weevil management through cotton stalk destruction, pp. 216-218. In Proceedings of the Beltwide Cotton Conference, National Cotton Council, Memphis, TN.

Parrott, W. L., J. N. Jenkins, and W. T. Buford. 1970. Instars and duration of stadia of boll weevil larvae. Ann. Entomol. Soc. Am. 63: 1265-1267.

Reynolds, H. T., P. L. Adkisson, and R. F. Smith. 1975. Cotton pest management, pp. 379-443. In R. L. Metcalf and W. H. Luckman [eds.], Introduction to insect pest management, Wiley, New York

Showler, A. T. 2003. Effects of routine late-season field operations on numbers of boll weevils (Coleoptera: Curculionidae) captured in large-capacity pheromone traps. J. Econ. Entomol. 96: 680-689.

Smart, J. R., and J. M. Bradford. 1996. No-tillage and reduced tillage cotton production in south Texas, pp. 13971401. In Proceedings of the Beltwide Cotton Conference, National Cotton Council, Memphis, TN.

Sokal, R. R., and F. J. Rohlf. 1994. Biometry: the principles and practice of statistics in biological research. Freeman, San Francisco, CA

Sterling, W. L., A. Dean, A. Hartstack, and J. Witz. 1990. Partitioning boll weevil (Coleoptera: Curculionidae) mortality associated with high temperature: desiccation or thermal death? Environ. Entomol. 19: 1457-1462.

Stevens, W. E., J. R. Johnson, J. J. Varco, and J. Parkman. 1992. Tillage and winter cover management effects on fruiting and yield of cotton. J. Prod. Agric. 5: 570-575.

Sturm, M. M., and W. L. Sterling. 1986. Boll weevil mortality factors within flower buds of cotton. Bull. Entomol. Soc. Am. 32: 239-247.

Summy, K. R., W. G. Hart, J. R. Cate, and D. Bar. 1985. Research and areawide cotton stalk destruction for cultural control of boll weevil in the Lower Rio Grande Valley, pp. 145. In Proceedings of the Beltwide Cotton Conference, National Cotton Council, Memphis, TN.

Summy, K. R., W. G. Hart, M. D. Heilman, and J. R. Cate. 1986. Late season boll weevil control: combined impact of stalk shredding and lethal soil temperatures, pp. 233235. In Proceedings of the Beltwide Cotton Conference, National Cotton Council, Memphis, TN.

Summy, K. R., and E. G. King. 1992. Cultural control of cotton insect pests in the United States. Crop Prot. 11: 307-319.

Summy, K. R., J. R. Cate, and D. Bar. 1993a. Overwinter survival of boll weevil in South Texas: Entrapment in desiccated bolls. J. Econ. Entomol. 86: 421-426.

Summy, K. R., J. R. Cate, and D. Bar. 1993b. Overwinter survival of boll weevil in South Texas: Evidence and significance of reproduction diapause. J. Econ. Entomol. 86: $369-376$.

Troxclair, N. N., Jr., and D. J. Boethel. 1984. Influence of tillage practices and row spacing on soybean insect populations in Louisiana. J. Econ. Entomol. 77: 1571-1579.

Wilkinson, L., M. A. Hill, and E. Yang. 1992. SYSTAT: Statistics, version 5.2. Systat, Inc., Evanston, IL.

Received 25 June 2003; accepted 29 November 2003. 